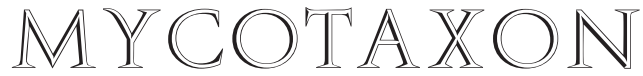

Volume 123, pp. 457-465

http://dx.doi.org/10.5248/123.457

January-March 2013

\title{
Molecular characterization of Colletotrichum species causing soybean anthracnose in Argentina
}

\author{
Araceli M. Ramos ${ }^{1}$, Luis Franco Tadic ${ }^{1}$, Isabel Cinto ${ }^{1, *}$, \\ Marcelo Carmona ${ }^{2}$ \& Marcela Gally ${ }^{2}$ \\ ${ }^{1}$ Departamento BBE, Lab. 9, FCEN (UBA), PROPLAME-PRHIDEB (CONICET) \& \\ ${ }^{2}$ Cátedra de Fitopatología, Facultad de Agronomía, UBA C.A.B.A. Argentina \\ *CorresPondence To isa.cinto@gmail.com oricinto@bg.fcen.uba.ar
}

Abstract - Twenty-six isolates obtained from soybean crops (Glycine max) with typical anthracnose symptoms were identified as Colletotrichum truncatum $(73 \%)$ and C. destructivum (26\%). Their genetic relationships were studied using the AFLP method. A UPGMA phenogram divided the strains into two clusters corresponding with the two species. Genetic distances based on association coefficient were $0.71-0.89$ among the $18 \mathrm{C}$. truncatum strains and $0.67-1$ among the eight $C$. destructivum strains. Genetic variability within species, measured in terms of percentage of polymorphic loci, was high $(<90 \%)$. Only two isolates showed $100 \%$ similarity, suggesting high intraspecific variability.

KEY wORDs - Glomerella glycines, teleomorph, genetic diversity

\section{Introduction}

Soybean (Glycine max (L.) Merr.) is the most important crop in Argentina, with late-season diseases caused by Septoria glycines, Cercospora kikuchii, Phomopsis sojae, Colletotrichum destructivum, and C. truncatum causing major losses (Carmona et al. 2009, 2011).

The two anthracnose pathogens most frequently associated with soybean are Colletotrichum truncatum (Schwein.) Andrus \& W.D. Moore and C. destructivum O'Gara, [= Glomerella glycines Lehman \& F.A. Wolf]. The traditional characterization and identification of Colletotrichum species has relied on morphological differences (Sutton 1992). Molecular markers constitute the current choice to obtain diagnostic characters as an aid for species-level identification and to evaluate genetic diversity. The amplified fragment length polymorphism (AFLP) method (Vos et al. 1995) is frequently used to monitor the identity of an isolate or to determine the degree of similarity among isolates, owing to certain advantages over other techniques (i.e. high level of identified polymorphism, high reproducibility, relative technical simplicity; Briad et 
al. 2000). The taxonomy and nomenclature of the anthracnose pathogens (Colletotrichum spp.) is confusing (Hyde et al. 2009 a) and have recently been summarised by Hyde et al. (2009b), incorporating data obtained by DNA analysis and phylogenetic systematics.

Physiological studies have been performed on C. truncatum isolates obtained from soybean plants in Argentina (Levin et al. 2007, Ramos et al. 2010), but the genetic structure of anthracnose fungi associated with the Argentinean soybean crop is not available. Our study aimed to evaluate genetic variability and genetic relationships within Colletotrichum species obtained from symptomatic soybean plants in Argentina.

\section{Materials \& methods}

\section{Fungal Isolation}

Diseased soybean plants showing typical anthracnose symptoms were collected from different geographic locations in Argentina. The isolates were obtained from lesions of stems and pods, using the procedure of Levin et al. (2007).

All fungal strains used in this survey were deposited at the Herbarium and Culture Collection of the Departamento de Biodiversidad, Facultad de Ciencias Exactas y Naturales Universidad de Buenos Aires (BAFC). TABLE 1 shows the collection locality and BAFC accession number of each strain used.

TABLE 1. Colletotrichum truncatum and C. destructivum fungal strains studied

\begin{tabular}{|c|c|c|}
\hline Species & COLLECTION LOCALITY ${ }^{*}$ & STRAINS TESTED \# \\
\hline \multirow[t]{14}{*}{ C. truncatum } & Godeken, SF, Arg. & C1 (3093) \\
\hline & Cerro Azul, SF, Arg. & C2 (3094) \\
\hline & Armstrong, SF, Arg. & C4 (3096), C5 (3097) \\
\hline & Cruz Alta, CO, Arg. & C6 (3098) \\
\hline & Fac. Agronomía CABA, Arg. & C7 (3099) \\
\hline & Lobos, BA, Arg. & C8 (3100), C9 (3101) \\
\hline & Saenz Peña, CH, Arg. & C10 (3102) \\
\hline & Salto, BA, Arg. & C14 (3396) \\
\hline & Las Lajitas, SA, Arg. & C15 (3397) \\
\hline & Piamonte, SF, Arg. & C26 (3398) \\
\hline & Otamendi, BA, Arg. & C24 (3399), C32 (3448) \\
\hline & Las Varillas, SF, Arg. & C25 (3400) \\
\hline & Fac. Agronomía CABA, Arg. & C29 (3443), C30 (3444) \\
\hline & Venado Tuerto, SF, Arg. & C31 (3447) \\
\hline \multirow[t]{7}{*}{ C. destructivum } & Urdinarrain, ER, Arg. & C16 (3434) \\
\hline & Chivilcoy, BA, Arg. & C17 (3435) \\
\hline & Río Cuarto, CO, Arg. & C18 (3436) \\
\hline & 9 de Julio, BA, Arg. & C19 (3437) \\
\hline & Barranca Yaco, SF, Arg. & C21 (3439) \\
\hline & Piamonte, SF, Arg. & C23 (3441) \\
\hline & Chivilcoy, BA. Arg. & C27 (3401), C28 (3442) \\
\hline
\end{tabular}

* Abbreviations: $\mathrm{BA}=$ Buenos Aires Province; CABA = Ciudad Autónoma de Buenos Aires; $\mathrm{CH}=$ Chaco Province; $\mathrm{CO}=$ Córdoba Province; $\mathrm{ER}=$ Entre Ríos Province; LR = La Rioja Province; $\mathrm{SA}=$ Salta Province; $\mathrm{SF}=$ Santa Fé Province; Arg.: = Argentina.

\# Numbers in parentheses correspond to the BAFC culture number (see Materials \& methods). 
TABLE 2. AFLP primers used in this study

\begin{tabular}{|c|c|}
\hline Primers & SEQUENCE $5^{\prime}-3^{\prime}$ \\
\hline $\mathrm{E}+\mathrm{AC}$ & GAC TGC GTA CCA ATT CAC \\
\hline $\mathrm{E}+\mathrm{AA}$ & GAC TGC GTA CCA ATT CAA \\
\hline $\mathrm{E}+\mathrm{ACG}$ & GAC TGC GTA CCA ATT CAC G \\
\hline $\mathrm{E}+\mathrm{AAC}$ & GAC TGC GTA CCA ATT CAA C \\
\hline $\mathrm{E}+\mathrm{AAG}$ & GAC TGC GTA CCA ATT CAA G \\
\hline $\mathrm{M}+\mathrm{A}$ & GAT GAG TCC TGA GTA AA \\
\hline$M+G$ & GAT GAG TCC TGA GTA AG \\
\hline $\mathrm{M}+\mathrm{C}$ & GAT GAG TCC TGA GTA AC \\
\hline $\mathrm{M}+\mathrm{T}$ & GAT GAG TCC TGA GTA AT \\
\hline
\end{tabular}

\section{DNA extraction}

Actively growing mycelia were obtained and then ground in liquid nitrogen (Ramos et al. 2000). Genomic DNA was extracted following Gottlieb \& Lichtwardt (2001). Quality control and quantification of genomic DNA was carried out by agarose gel $(0.8 \% \mathrm{w} / \mathrm{v})$ electrophoresis and by comparison with a DNA molecular-size standard (Lambda EcoRI/HindIII, Promega Corp.). Gels, containing ethidium bromide, were photographed under UV light.

\section{AFLP}

The AFLP methodology was carried out on $250 \mathrm{ng}$ of genomic DNA using the AFLP $^{\circledR}$ Analysis System for Microorganisms Primer Kit (Invitrogen) as described in the instructions manual with minor modifications (Gottlieb et al. 2005). Selective primers used herein, containing one, two or three additional bases, were combined as in TABLE 2 . All PCR amplifications were performed in a Techne Progene thermal cycler.

Polyacrylamide gel electrophoresis conditions were conducted as in Gottlieb et al. (2005). A 30-330-bp AFLP ${ }^{\circ}$ DNA Ladder (Invitrogen) size marker was included twice in each electrophoresis run. Thus, the size of scored AFLP bands ranged from 90 to 330 bp. AFLP bands were visualized using the Silver Sequence TM DNA Sequencing System (Promega). Air-dried gels were digitalized and visually analyzed using the Adobe Photoshop TM (Adobe Systems, Mountain View, CA, USA).

\section{Data analysis}

Each AFLP band, regardless of its relative intensity, was considered as a dominant allele at only one locus. The data, as either present (1) or absent (0), were extracted as a table. Monomorphic bands (bands present in all individuals of a species) were discriminated within each species and across the entire data set. The binary matrix was analyzed with the program NTSYS-PC version 2.02i (Rohlf 1993). The unweighted pair-group method with arithmetic mean (UPGMA) cluster analysis was performed based on the simple matching (SM), Jaccard (J), and Dice (D) association coefficients (Sneath \& Sokal 1973). Phenograms showing similarity relations were generated by the same program, with the tree display option (TREE). Correlation cophenetic coefficients (r) were calculated for each association coefficient (Sokal \& Rohlf 1962). A cophenetic correlation (r) of 0.8 was considered a good fit. A three-dimensional graphic was obtained with the Principal Coordinates ordination method (Gower 1966).

The percentage of polymorphic loci $(\mathrm{P}=$ number of polymorphic loci/ number of loci analyzed) for each primer combination was calculated. 


\section{Results}

Twenty-six isolates obtained from soybean crops that showed typical anthracnose symptoms were identified as Colletotrichum truncatum (73\%) and C. destructivum (26\%), based on their morphological characteristics (Sutton 1992).

\section{Characterization of AFLP markers}

Six primers (TABLE 3) that produced high numbers of clear, reproducible bands by AFLP amplification were selected. The analysis of the six primers yielded a total of 812 bands that appeared consistently in all experiments among the amplified fragments of the 26 isolates. The size of the amplified bands ranged from 50 to 550 bp but we analyzed only bands from 90 to $330 \mathrm{bp}$.

The total number of AFLP bands (polymorphic and monomorphic) obtained and the percentage of polymorphic loci for each selective primer combination in two fungal species assayed are described in TABLE 3. All primers detected a high number of polymorphic bands within species and a high percentage of polymorphic loci was obtained.

TABLE 3. Total AFLP bands (polymorphic and monomorphic) detected for each primer combination in each assayed fungal species with polymorphic loci percentages $(\mathrm{P} \%)$.

\begin{tabular}{llcccc}
\hline $\begin{array}{l}\text { Primer } \\
\text { COMbination }\end{array}$ & Species & $\begin{array}{c}\text { Total } \mathrm{N}^{\circ} \\
\text { OF Bands }\end{array}$ & $\begin{array}{c}\text { Polymorphic } \\
\text { Bands }\end{array}$ & $\begin{array}{c}\text { Monomorphic } \\
\text { Bands }\end{array}$ & P\% \\
\hline \multirow{2}{*}{$\mathrm{M}+\mathrm{T} / \mathrm{E}+\mathrm{ACG}$} & C. truncatum & 73 & 65 & 8 & 89 \\
& C. destructivum & 81 & 74 & 7 & 91 \\
\hline \multirow{2}{*}{$\mathrm{M}+\mathrm{C} / \mathrm{E}+\mathrm{AAG}$} & C. truncatum & 117 & 111 & 6 & 95 \\
& C. destructivum & 111 & 109 & 2 & 98 \\
\hline \multirow{2}{*}{$\mathrm{M}+\mathrm{A} / \mathrm{E}+\mathrm{AAG}$} & C. truncatum & 95 & 93 & 2 & 98 \\
& C. destructivum & 56 & 51 & 5 & 91 \\
\hline \multirow{2}{*}{$\mathrm{M}+\mathrm{A} / \mathrm{E}+\mathrm{ACG}$} & C. truncatum & 73 & 71 & 2 & 97 \\
& C. destructivum & 100 & 96 & 4 & 96 \\
\hline \multirow{2}{*}{$\mathrm{M}+\mathrm{G} / \mathrm{E}+\mathrm{ACG}$} & C. truncatum & 82 & 80 & 2 & 97 \\
& C. destructivum & 54 & 52 & 2 & 96 \\
\hline \multirow{2}{*}{$\mathrm{M}+\mathrm{A} / \mathrm{E}+\mathrm{AAC}$} & C. truncatum & 103 & 82 & 21 & 79 \\
& C. destructivum & 56 & 48 & 8 & 86 \\
\hline
\end{tabular}

Only $41(7.6 \%)$ of the bands obtained in C. truncatum and 28 (6.1\%) in C. destructivum were monomorphic. Genetic variability within species, measured in terms of percentage of polymorphic loci, was high: C. truncatum $(\mathrm{P}=92 \%)$ and $C$. destructivum $(\mathrm{P}=94 \%)$.

The UPGMA phenogram (FIgURE 1) grouped all strains into two defined clusters with a SM coefficient of 0.6 between them. The main cluster included 


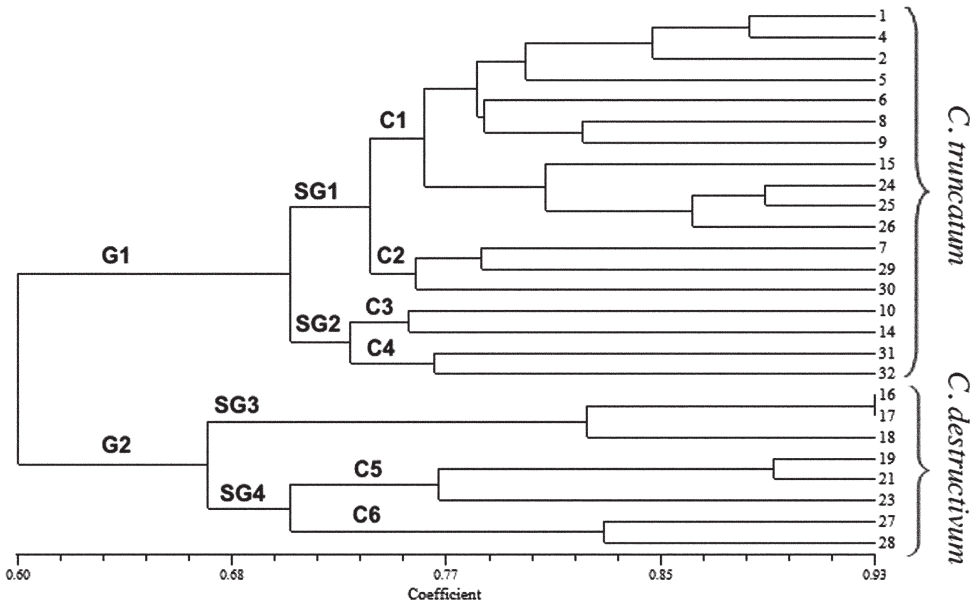

FIgURE 1. UPGMA phenogram showing relationships of Colletotrichum truncatum and C. destructivum isolates based on the simple matching (SM) association coefficient estimated from AFLP loci.

the 18 isolates identified as C. truncatum (FIgURE 1, G1), whereas the other (FIgUre 1, G2) included the eight isolates identified as C. destructivum. There was no direct correlation between molecular genotype and geographic origin.

\section{Genetic distance and cluster analysis}

The phenogram obtained using the UPGMA method was constructed based on Simple Matching (SM) coefficients. Little distortion occurred while constructing this phenogram, as implied by the value of the correlation cophenetic coefficient $(\mathrm{r}=0.91903)$.

The main group (FIGURE 1, G1) comprised two subgroups (SG1 and SG2), one with 14 isolates and two conjuncts (C1 and C2), and the other (SG2) with two conjuncts (C3 and $\mathrm{C} 4$ ), each with two isolates. Group 2, formed by C. destructivum isolates, showed two subgroups, SG3 formed by three isolates (16, 17 and 18), and SG4, which included conjunct C5 and C6 formed by the rest of isolates belonging to $C$. destructivum. The relatedness of the 18 isolates of C. truncatum was $0.71-0.89$, whereas that among the 8 isolates of $C$. truncatum was $0.67-1$. Only two isolates ( 16 and 17 , SG3) showed $100 \%$ similarity.

The three-dimensional graphic generated by the ordination technique distinguished two groups (FIGURE 2, GI and GII) and showed nearly the same relations between isolates as the phenogram (FIGURE 1). The first group included the 18 isolates belonging to C. truncatum, which are slightly differentiated in 


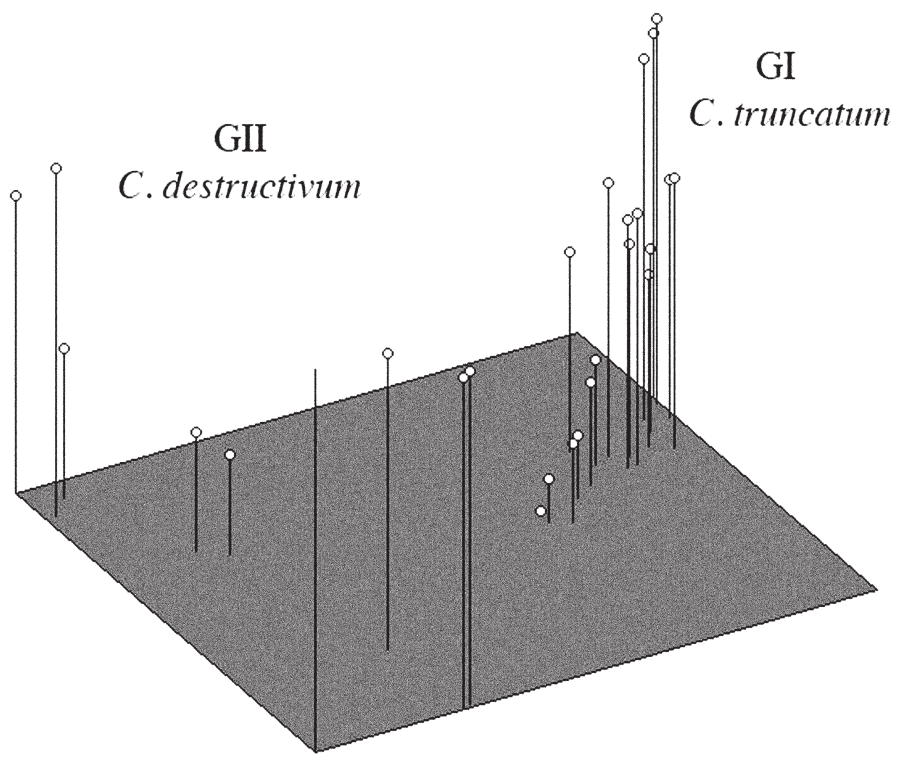

FIgURE 2. Three-dimensional graphic obtained with the Principal Coordinates ordination technique.

axis 1 and largely separated in the other two axes. The second group showed the seven isolates of $C$. destructivum largely separated in axis 1 and moderately differentiated in axes 2 and 3. Group GI included isolates of SGI and SGII of the phenogram and group GII comprised the isolates of SGIII and SGIV.

\section{Discussion}

C. truncatum and C. destructivum are highly variable pathogens in Argentina. Sharma (2009) also reported a high degree of variability among different isolates of C. truncatum studied through Random Amplified Polymorphic DNA (RAPD) analysis.

Perithecia of the $C$. destructivum teleomorph (the state referred to in dual nomenclature as Glomerella glycines) are frequently found in the fields of Argentina, indicating that the sexual mechanism is an important source of variability in the populations of this species. However, sexual recombination in most Colletotrichum species is rare in nature (Wharton \& Diéguez-Uribeondo 2004; Hyde et al. 2009b).

Nevertheless, in our study, we found a high degree of variability in the populations analyzed. Alternatives to sexual recombination for genetic interaction among fungi are heterokaryosis and mitotic recombination (Esser 
\& Kuenen 1967). In many Colletotrichum populations, the only means of exchanging genetic material between two strains is mainly or exclusively vegetative, by means of anastomosis and heterokaryosis (Correll et al. 2000). These processes have been studied in some Colletotrichum species (Vaillancourt 1994; Correll et al. 1993; Elmer 2001; Nitzan et al. 2002; Rodriguez-Guerra et al. 2003; Barcelos et al. 2011). Sant'Anna et al. (2010) related genetic diversity analyzed by RAPD with the presence of vegetative compatibility groups in C. truncatum, and concluded that the parasexual process might be an important factor to increase the genetic variability in the pathogen.

Almost the entire soybean crop area of Argentina is cultivated under no-tillage systems. The crop debris remaining on the soil surface provides optimum conditions for the active development of reproductive structures of C. truncatum and C. destructivum. Any event of mutation or sexual or vegetative recombination is enhanced by the high reproductive rate occurring in these conditions. Gene flow and migration forces seem to be relatively unimportant due to the weak dispersal ability of the spores, as both conidia and ascospores are immersed in a mucous matrix, which prevents dispersal, by wind. The only possibility of migration to long distances is by means of seed transmission. Nevertheless, both species are not frequent seed pathogens in the Pampean Region.

The level of genetic variability within populations of plant pathogens provides an indication of their adaptability of pathogen in overcoming plant resistance and other measures used to control the pathogen, such as the application of fungicides in agro-ecosystems (McDonald et al. 1989; McDonald \& Linde 2002). In our study, the high genetic diversity indicates increasing fitness of the population.

This paper constitutes the first report of genetic variability in C. truncatum and $C$. destructivum isolates collected from different soybean growing areas in Argentina.

\section{Acknowledgments}

This study was supported by a grant from Consejo Nacional de Investigaciones Científicas y Técnicas (CONICET) and University of Buenos Aires, Argentina. The authors thank Dr. S. Lupo (Universidad de la República, Montevideo, Uruguay) and Dr. E.M. Reis (University of Passo Fundo, Brazil) for expert presubmission review.

\section{Literature cited}

Barcelos QL, Souza EA, Damasceno e Silva KJ. 2011. Vegetative compatibility and genetic analysis of Colletotrichum lindemuthianum isolates from Brazil. Genet. Mol. Res. 10: 230-242. http://dx.doi.org/10.4238/vol10-1gmr907

Briard M, Le Clerc V, Grzebelus LD, Senalik D, Simon PW. 2000. Modified protocols for rapid carrot genomic DNA extraction and AFLP TM analysis using silver stain or radioisotopes. Plant Molecular Biology Reporter 18: 235-241. http://dx.doi.org/10.1007/BF02823994 
Carmona M, Scandiani M, Luque A. 2009. Severe outbreaks of soybean frogeye leaf spot caused by Cercospora sojina in the Pampean Region, Argentina. Plant Disease 93: 966.

http://dx.doi.org/10.1094/PDIS-93-9-0966B

Carmona M, Sautua F, Reis EM, Prerlman S, Gally M. 2011. Relationship between late soybean diseases complex and rain in determining grain yield responses to fungicide applications. J. Phytopathol. 159: 687-693. http://dx.doi.org/10.1111/j.1439-0434.2011.01828.x

Correll JC, Morelock TE, Guerber JC. 1993. Vegetative, compatibility and virulence of the spinach anthracnose pathogen, Colletotrichum dematium. Plant Disease 77: 688-691. http://dx.doi.org/10.1094/PD-77-0688

Correll JC, Guerber JC, Walsiwa LA, Sherril JF, Morelock TE. 2000. Inter and intra species variation in Colletotrichum and mechanism which affect population structure. 145-179, in: D Prusky et al. (eds). Colletotrichum: host specificity, pathology, and host-pathogen interaction. The American Phytopathological Society. St. Paul MN.

Elmer WH, Yang HA, Sweetingham MW. 2001. Characterization of Colletotrichum gloeosporioides isolates from ornamental lupines in Connecticut. Plant. Dis. 85: 216-219. http://dx.doi.org/10.1094/PDIS.2001.85.2.216

Esser K, Kuenen R. 1967. Genetics of fungi. Springer-Verlag, New York. http://dx.doi.org/10.1007/978-3-642-86814-6

Gottlieb AM, Lichtwardt RW. 2001. Molecular variation within and among species of Harpellales. Mycologia 93: 65-80. http://dx.doi.org/10.2307/3761606

Gottlieb AM, Giberti GC, Poggio L. 2005. Molecular analyses of the genus Ilex (Aquifoliaceae) in southern South America, evidence from AFLP and ITS sequence data. American Journal of Botany 92: 352-369. http://dx.doi.org/10.3732/ajb.92.2.352

Gower JC. 1966. Some distance properties of latent root and vector methods used in multivariate analysis. Biometrika 53: 325-338.

Hyde KD, Cai L, McKenzie EHC, Yang YL, Zhang JZ, Prihastuti H. 2009a. Colletotrichum: a catalogue of confusion. Fungal Diversity 39: 1-17.

Hyde KD, Cai L, Cannon PF, Crouch JA, Crous PW, Damm U, Goodwin PH, Chen H, Johnston PR, Jones EBG, Liu ZY, McKenzie EHC, Moriwaki J, Noireung P, Pennycook SR, Pfenning LH, Prihastuti H, Sato T, Shivas RG, Tan YP, Taylor PWJ, Weir BS, Yang YL, Zhang JZ. 2009b. Colletotrichum - names in current use. Fungal Diversity 39: 147-182.

Levin L, Ramos AM, Parisi M, Gally M. 2007. Screening of Colletotrichum (Ascomycota) isolates causal agents of soybean anthracnose, for laccase production. Boletín de la Sociedad Argentina de Botánica 42: 71-77.

McDonald BA, Linde C. 2002. Pathogen population genetics, evolutionary potential, and durable resistance. Ann. Rev. Phytopathol. 40: 349-379.

McDonald BA, McDermott JM, Goodwin SB, Allard RW. 1989. The population biology of hostpathogen interactions. Ann. Rev. Phytopathol. 27: 77-94. http://dx.doi.org/10.1146/annurev. py.27.090189.000453

Nitzan N, Hazanovsky M, Tal M, Tsror(Lahkim) L. 2002. Vegetative compatibility groups in Colletotrichum coccodes, the causal agent of black dot on potato. Phytopathology 92: 827-832. http://dx.doi.org/10.1094/PHYTO.2002.92.8.827

Ramos AM, Forchiassin F, Ranalli ME, Saidman B. 2000. Isozyme analysis of different species of the genus Saccobolus (Ascomycetes, Pezizales). Mycotaxon 74: 447-462

Ramos AM, Gally M, García MC, Levin L. 2010. Pectinolytic enzyme production by Colletotrichum truncatum, causal agent of soybean anthracnose. Rev. Iberoam. Micol. 27: 186-190. http://dx.doi.org/10.1016/j.riam.2010.06.002 
Rodríguez-Guerra R, Ramírez-Rueda MT, Martínez de la Vega O, Simpson J. 2003. Variation in genotype, pathotype and anastomosis groups of Colletotrichum lindemuthianum isolates from Mexico. Plant Pathology 52: 228-235. http://dx.doi.org/10.1046/j.1365-3059.2003.00808.x

Rohlf FJ. 1993. NTSYS-PC. Numerical taxonomy and multivariate analysis system Version 2.02i, Exeter Software Applied Biostatistics Inc., New York.

Sant’Anna JR, Miyamoto CT, Rosada LJ, Franco CCS, Kaneshima EN, Castro-Prado MA. 2010. Genetic relatedness of Brazilian Colletotrichum truncatum isolates assessed by vegetative compatibility groups and RAPD analysis. Biol. Res. 43: 51-62.

Sharma R. 2009. Genetic differentiation of host limited forms of Colletotrichum truncatum from northwestern Himalayas. Archives of Phytopathology and Plant Protection 42: 960-966. http://dx.doi.org/10.1080/03235400701543848

Sneath PH, Sokal RR. 1973. Numerical taxonomy: the principles and practice of numerical classification. San Francisco: W.H. Feeman \& Co.

Sokal RR, Rohlf JF. 1962. The comparison of dendrograms by objective methods. Taxon 11: 33-40. http://dx.doi.org/10.2307/1217208

Sutton BC. 1992. The genus Glomerella and its anamorph Colletotrichum. 1-26, in: JA Bailey, MJ Jeger (eds). Colletotrichum: biology, pathology and control. CAB International, Wallingford, UK.

Vaillancourt LJ, Hanau R. 1994. Nitrate-Nonutilizing mutants used to study heterokaryosis and vegetative compatibility in Glomerella graminicola. (Colletotrichum graminicola). Exp. Mycology 18, 311-319. http://dx.doi.org/10.1016/S0147-5975(06)80004-6

Vos P, Hogers R, Bleeker M, Reijans M, Lee TV, Hornes M, Frijters A, Pot J, Peleman J, Kuiper M, Zabeau M. 1995. AFLP: a new technique for DNA fingerprinting. Nucl. Acids Res. 23: 4407-4414. http://dx.doi.org/10.1093/nar/23.21.4407.

Wharton PS, Diéguez-Uribeondo J. 2004. The biology of Colletotrichum acutatum. Anales del Jardín Botánico de Madrid 61(1): 3-22. http://dx.doi.org/10.3989/ajbm.2004.v61.i1.61 